\title{
Photomodification by Rose Bengal of NAD(P)H-Nitrate Reductase of Hansenula anomala
}

\author{
Nobuko Minagawa and Akio Yoshimoto \\ Department of Biochemistry, Niigata College of Pharmacy, \\ Niigata, Niigata 950-21, Japan \\ Received January 12, 1984
}

\begin{abstract}
The photoillumination of assimilatory nitrate reductase of Hansenula anomala in the presence of Rose Bengal caused a selective inactivation of $\mathrm{NAD}(\mathrm{P}) \mathrm{H}$-linked activities. The potent protective effect of NAD(P)H suggests that the residue(s) modified by the treatment is involved in electron transport from NAD $(\mathrm{P}) \mathrm{H}$. From the observation that $p$-chloromercuribenzoate-treated enzyme was potomodified similarly to the native enzyme, the photomodified residue(s) is deduced not to be cysteine. The parallel decrease of NAD $(\mathrm{P}) \mathrm{H}$-nitrate reductase activity and the histidine contents suggests that histidine residue(s) is involved in this inactivation.
\end{abstract}

In the ascomycetous yeast Hansenula anomala, the assimilatory reduction of nitrate to nitrite is catalyzed by $\mathrm{NAD}(\mathrm{P}) \mathrm{H}$-nitrate oxidoreductase (EC 1.6.6.2), ${ }^{1,2)}$ which generally contains FAD, cytochrome $b-557$, and molybdenum as intramolecular electron carriers. ${ }^{3)}$ This enzyme also catalyzes the reduced flavin and reduced viologen dye-dependent nitrate reduction and $\mathrm{NAD}(\mathrm{P}) \mathrm{H}$-diaphorase-like reaction. $^{3)} \mathrm{NAD}(\mathrm{P}) \mathrm{H}$-linked activities require exogenous FAD, which is rather loosely bound to the enzyme from fungi. ${ }^{2)}$

The assimilatory nitrate reductases from green algae and fungi can exist in vivo in two interconvertible forms (active and inactive), which are thought to be related to the molybdenum center of the nitrate reductase molecule. $^{3,4)}$ Several authors have demonstrated the blue light-dependent reactivation of inactive nitrate reductases. ${ }^{5}$ 7) Roldán and Butler reported the involvement of FAD, as a photoreceptor, and oxygen in the reactivation process of cyanide-inactivated enzyme. ${ }^{7)}$ On the other hand, inactivation by illuminated flavins has been demonstrated. ${ }^{8,9)}$ Vargas et al. suggest the involvement of singlet oxygen gen- erated by photosensitized flavins in the inactivation process. ${ }^{9)}$

In this paper we report the photomodification of assimilatory nitrate reductase of $H$. anomala in the presence of Rose Bengal, which is thought to generate singlet oxygen upon aerobic irradiation. ${ }^{10)}$ Our results strongly suggest that the Rose Bengal-generated singlet oxygen modified the residue(s) involved in the electron transport at the inlet of NAD(P)H. And from the observation that $p$-chloromercuribenzoate (PCMB)-treated enzyme was photomodified similarly to the native enzyme, the modified residue(s) is thought not to be thiol group(s) of cysteine. Further, the amino acid analysis and the modification by ethoxyformic anhydride (EFA) suggest that histidine residues are involved in the NAD $(\mathrm{P}) \mathrm{H}$-linked activities.

\section{MATERIALS AND METHODS}

Materials. Rose Bengal was purchased from CHROMA, pyridine nucleotides from Oriental Yeast, PCMB from Nakarai Chemical Co., and $\mathrm{D}_{2} \mathrm{O}$ from Merck. Egg white trypsin inhibitor and glucose oxidase

Abbreviations: PCMB; $p$-chloromercuri benzoate, EFA; ethoxyformic anhydride, GOD; glucose oxidase, MVH; reduced methyl viologen. 
(GOD) were obtained from Boehringer, and bovine liver catalase from Sigma. DEAE-cellulose was purchased from Brown and DEAE Affi-Gel Blue from Bio-Rad. Hydroxylapatite was prepared according to Main et al. ${ }^{11)}$

Cell growth and enzyme purification. Hansenula anomala(strain LKBY-1, donated by Dr. Kodama, Kodama Brewing Co., Ltd.) was grown in the liquid medium described by Minagawa and Yoshimoto. ${ }^{2)}$ Fifteen hrs-old cells $(120 \mathrm{~g})$ were disrupted as in our previous report with the further addition of egg white trypsin inhibitor $(0.25 \mathrm{mg} / \mathrm{ml})$ instead of $0.6 \mathrm{M}$ sorbitol. ${ }^{2)}$ Potassium phosphate buffer ( $\mathrm{pH} 7.4$ ) containing $20 \mu \mathrm{M}$ FAD and $1 \mathrm{~mm}$ EDTA were used throughout the purification steps. Crude extract was fractionated by ammonium sulfate precipitation (33 50\% saturation), desalted through a Sephadex G-50 column $(4 \times 20 \mathrm{~cm})$ equilibrated with $50 \mathrm{~mm}$ buffer, and then applied on a column of DEAE-cellulose $(2.2 \times 6 \mathrm{~cm})$ equilibrated with $50 \mathrm{~mm}$ buffer and eluted stepwise with $200 \mathrm{~mm}$ phosphate buffer. The fractions containing enzyme activity were combined and diluted to $50 \mathrm{~mm}$ phosphate concentration, and then applied on a column of DEAE Affi-Gel Blue $(1.8 \times 3.2 \mathrm{~cm})$ and eluted with a linear gradient from 50 to $400 \mathrm{~mm}$ phosphate $(150 \mathrm{ml})$. The fractions of high enzyme activity were combined and diluted to give a conductivity equivalent to $50 \mathrm{~mm}$ buffer. The diluted solution was applied on a column of hydroxylapatite $(1.6 \times 8.3 \mathrm{~cm})$ equilibrated with $50 \mathrm{~mm}$ buffer and eluted with a linear gradient from 50 to $400 \mathrm{~mm}$ phosphate $(200 \mathrm{ml})$. The final preparation (specific activity; $34 \mu \mathrm{mol}$ nitrite formed/ $\mathrm{min} / \mathrm{mg}$ ) was obtained in $5 \%$ yield.

Assays of nitrate reductase activity. The determination of the enzyme activities was carried out as previously reported. ${ }^{12)}$

Amino acid analysis. Protein was hydrolyzed with twicedistilled $6 \mathrm{~N} \mathrm{HCl}$ at $110^{\circ} \mathrm{C}$ for $22 \mathrm{hr}$ in evacuated and sealed glass tubes. Amino acids were analyzed with a JEOL JLC6AS amino acid analyzer by the method of Spackman et al. ${ }^{13)}$

Conditions of photooxidation. Nitrate reductase in $50 \mathrm{~mm}$ of potassium phosphate $(\mathrm{pH} 7.4)$ was illuminated at $4^{\circ} \mathrm{C}$ in glass test tubes $(4 \times 50 \mathrm{~mm})$ using a projector $(\mathrm{CABIN}$, Family CABIN) equipped with a tungsten halogen lamp (SYLVANIA, JC 24V-150W) at a distance of $30 \mathrm{~cm}$ in conjunction with $340 \mathrm{~nm}$ sharp cut-off filter (Hoya Glass Works, UV-34) and heat-blocking filter $\left(1 \% \mathrm{CuSO}_{4}\right.$. $5 \mathrm{H}_{2} \mathrm{O}$ aqueous solution, $3.5 \mathrm{~cm}$ thick) unless otherwise indicated.

\section{RESULTS}

The nitrate reductase from $H$. anomala catalyzes four kinds of reduction; $\mathrm{NAD}(\mathrm{P}) \mathrm{H}$ - dependent nitrate reduction and cytochrome $c$ reduction (diaphorase-like reaction), reduced flavin-dependent nitrate reduction, and reduced viologen dye-dependent nitrate reduc-

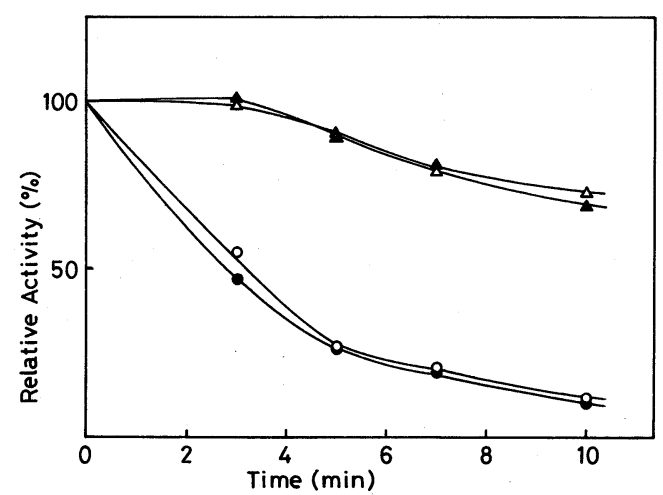

FIG. 1. Effects of Illumination in the Presence of Rose Bengal on NADPH-Nitrate Reductase and Associated Activities.

The enzyme $(50 \mu \mathrm{l}, 0.32 \mathrm{mg} / \mathrm{ml}, 31 \mathrm{unit} / \mathrm{mg})$ containing $5 \mu \mathrm{M}$ Rose Bengal was illuminated at $4^{\circ} \mathrm{C}$ as in the text. The samples were assayed for the reductase activities at the indicated times. The results were compared with those obtained with the enzyme sample kept in the dark. NADPH-nitrate reductase activity; $\mathrm{O}$, NADPHcytochrome $c$ reductase activity; $\mathbf{\Delta}, \mathrm{FADH}_{2}$-nitrate reductase activity; $\triangle, \mathrm{MVH}$-nitrate reductase activity.

\section{TABLE I. EFFECTS OF OXYGEN ON THE PHOTOMODIfICATION OF Nitrate ReDUCTASE}

The enzyme samples containing $5 \mu \mathrm{M}$ Rose Bengal $(50 \mu \mathrm{l}, \quad 0.64 \mathrm{mg} / \mathrm{ml}, 32 \mathrm{unit} / \mathrm{mg})$ were illuminated for $10 \mathrm{~min}$ under aerobic and anaerobic conditions. For anaerobic incubation, the glass test tube containing $0.53 \mathrm{mg} / \mathrm{ml}$ of GOD, $50 \mathrm{~mm}$ glucose, and $0.30 \mathrm{mg} / \mathrm{ml}$ of catalase was sealed after argon substitution. After illumination for $10 \mathrm{~min}$, NADPH-nitrate reductase activity was determined on aliquots of the incubation mixture. The activities are expressed as percent of residual activity.

\begin{tabular}{lccc}
\hline Atmosphere & $\begin{array}{c}\text { GOD } \\
\text { glucose } \\
\text { catalase }\end{array}$ & Light & $\begin{array}{c}\text { NADPH } \rightarrow \mathrm{NO}_{3}^{-} \\
\text {Residual } \\
\text { activity }(\%)\end{array}$ \\
\hline Air & - & + & 5 \\
Air & - & - & 97 \\
Argon & + & + & 24 \\
Argon & + & - & 93 \\
& - & + & 68 \\
& + & - & 103 \\
& + & + & 105 \\
\hline
\end{tabular}




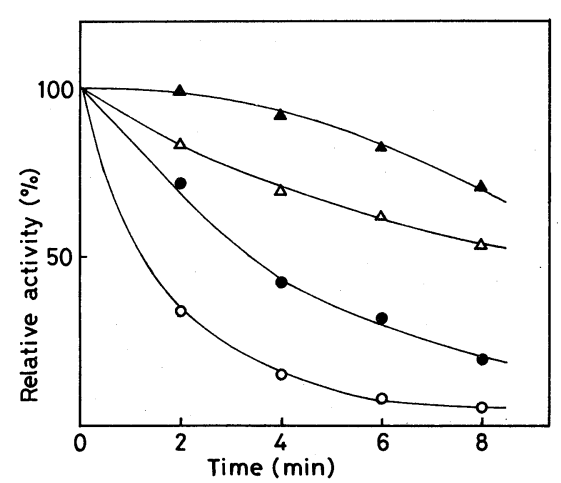

FIG. 2. Effects of $\mathrm{D}_{2} \mathrm{O}$ on the Photomodification of Nitrate Reductase in the Presence of Rose Bengal.

The enzyme $(200 \mu \mathrm{l}, 0.36 \mathrm{mg} / \mathrm{ml}, 32 \mathrm{unit} / \mathrm{mg})$ containing $5 \mu \mathrm{M}$ Rose Bengal was illuminated at $4^{\circ} \mathrm{C}$. The samples were withdrawn at the indicated times and assayed for the reductase activities. The results were compared with those obtained with the enzyme kept in the dark.

$\bigcirc$, NADPH-nitrate reductase activity; $\triangle \boldsymbol{\Delta}$, MVHnitrate reductase activity: Each open or closed symbol demonstrates the enzyme activities illuminated in $\mathrm{D}_{2} \mathrm{O}$ substituted $(90 \%)$ buffer or in normal buffer, respectively.

Table II. The Effect of Pyridine Nucleotides on the Photomodification of Nitrate Reductase

The enzyme samples $(50 \mu \mathrm{l}, 32 \mu \mathrm{g})$ were illuminated using a $400 \mathrm{~nm}$ cut-off filter (Fuji, SC-40) for $10 \mathrm{~min}$ as in Fig. 1 with or without the addition of pyridine nucleotides. Aliquots of the samples $(4 \mu \mathrm{l})$ were withdrawn and assayed for NADPH-nitrate reductase activity. The results were compared with the value obtained with the no addition control kept in the dark.

\begin{tabular}{ccc}
\hline \multirow{2}{*}{ Addition } & \multicolumn{2}{c}{ Residual activity $(\%)$} \\
\cline { 2 - 3 } & Dark & Light \\
\hline- & 100 & 6 \\
$1 \mathrm{~mm} \mathrm{NADPH}$ & 112 & 63 \\
$1 \mathrm{~mm} \mathrm{NADH}^{\mathrm{mm} \mathrm{NADP}}{ }^{+}$ & 107 & 58 \\
$1 \mathrm{~mm} \mathrm{NAD}^{+}$ & 103 & 16 \\
& 99 & 6 \\
\hline
\end{tabular}

tion. Figure 1 shows the effect of illumination on these four kinds of nitrate reductase activities in the presence of $5 \mu \mathrm{M}$ Rose Bengal. As can be seen, the selective inactivation of the two NADPH-linked activities occurred during the illumination.

Table I demonstrates the requirements for oxygen of the photoinactivation. Under an- aerobic conditions, no inactivation by illumination was observed. Therefore, oxygen is essential for the inactivation process.

Figure 2 shows the effect of substitution of $\mathrm{D}_{2} \mathrm{O}$ in the illumination system. $\mathrm{D}_{2} \mathrm{O}$ is thought to prolong the life of singlet oxygen and facilitate the effect of this active oxygen species. ${ }^{10}$ ) The substitution of $\mathrm{D}_{2} \mathrm{O}$ in the illumination system accelerates the inactivation rate of both NADPH- and reduced methyl viologen(MVH)-nitrate reductase activities.

Table II demonstrates the effects of pyridine nucleotides on the photomodification process. NADPH and NADH have a remarkable protective effect against the inactivation of NADPH-nitrate reductase activity. In contrast, $\mathrm{NADP}^{+}$and $\mathrm{NAD}^{+}$exhibited little protection against the photoinactivation. From these results the residue(s) modified during the illumination seems to be involved in the electron inlet from NAD(P)H.

In order to examine the possibility that the residue(s) modified by singlet oxygen might be cysteine, PCMB-treated enzyme was illuminated in the presence of Rose Bengal followed by the reactivation by GSH (Table III). PCMB-treated enzyme was photomodified quite similarly to the native enzyme. This observation strongly suggests that residue(s) other than cysteine participate in the intramolecular electron transport from $\mathrm{NAD}(\mathrm{P}) \mathrm{H}$.

The enzyme preparation used in this study was nearly homogeneous on disc gel electrophoresis (data are not shown). The course of changes in NADPH-nitrate reductase activity and histidine content during illumination in the presence of $1 \mu \mathrm{M}$ Rose Bengal is shown in Fig. 3. The decrease of histidine content followed first-order kinetics. NADPH-nitrate reductase activity decreased similarly until $6 \mathrm{~min}$. This result suggests the involvement of histidine residue(s) in the photoinactivation process.

Figure 4 shows the effects of $1 \mathrm{~mm}$ EFA on four kinds of nitrate reductase activities. Similarly to Fig. 1, there observed selective inactivation of NADPH-linked two activities. 


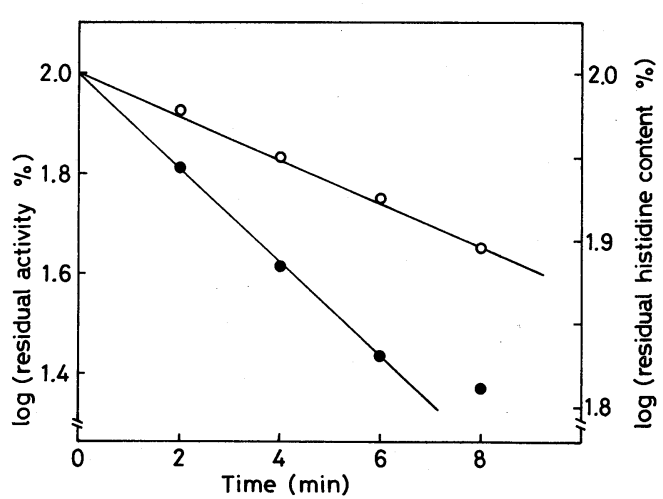

FIG. 3. Effects of Illumination in the Presence of Rose Bengal on NADPH-Nitrate Reductase Activity and Histidine Contents.

The enzyme $(2 \mathrm{ml}, 0.40 \mathrm{mg} / \mathrm{ml}, 34$ unit $/ \mathrm{mg})$ containing $1 \mu \mathrm{M}$ Rose Bengal was illuminated at $4^{\circ} \mathrm{C}$. The samples were withdrawn at the indicated times for NADPH-nitrate reductase activity and amino acid analysis. The samples of amino acid analysis were kept in the dark until $6 \mathrm{~N} \mathrm{HCl}$ were added. The results were plotted in $\log$ (percent of residual activity or contents). O, NADPH-nitrate reductase activity; $\bigcirc$, histidine contents.

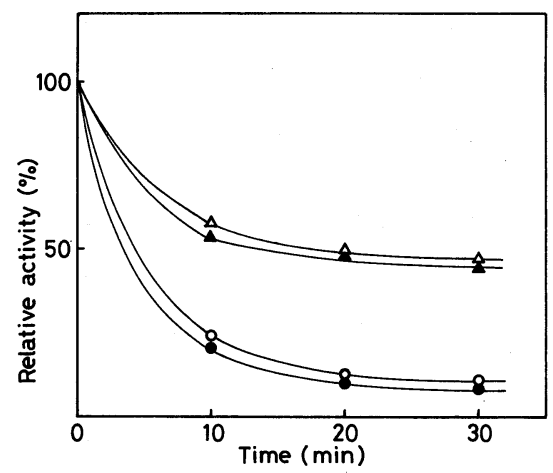

FIG. 4. Effects of Ethoxyformic Anhydride on NADPHNitrate Reductase and Associated Activities.

The enzyme ( $30 \mu \mathrm{l}, 93 \mu \mathrm{g}, 32 \mathrm{unit} / \mathrm{mg})$ containing $1 \mathrm{~mm}$ EFA and $20 \mu \mathrm{M}$ FAD was incubated at $20^{\circ} \mathrm{C}$. The results were compared with those obtained with the enzyme sample without EFA. NADPH-nitrate reductase activity; $\mathrm{O}, \mathrm{NADPH}$-cytochrome $c$ reductase activity; $\mathrm{FADH}_{2}$-nitrate reductase activity; $\triangle, \mathrm{MVH}$-nitrate reductase activity.

These results support the involvement of histidine residue(s) in the electron inlet from NAD(P)H.

\section{DISCUSSION}

Several authors have reported the photoinactivation of assimilatory nitrate reductase in the presence of flavins. ${ }^{8}{ }^{, 9}$ Although the data are not shown, we observed similar selective photomodification to that of Fig. 1 in the presence of photosensitizers such as FAD, FMN, riboflavin, Eosin $\mathrm{Y}$, and Methylene blue. In comparison with those photosensitizers, Rose Bengal induced the most effective and selective inactivation toward NAD(P)Hlinked activities in our experiment. The similar selective inactivation of NADPH-linked activities also occurs upon heat-treatment as reported on the enzyme of Aspergillus nidulans, ${ }^{12)}$ but in that case the concomitant increase of MVH-nitrate reductase activity can always be observed.

Vargas et al. suggested the involvement of singlet oxygen in the flavin-photosensitized inactivation process. ${ }^{9)}$ Our results also suggest that singlet oxygen generated during the aerobic illumination of Rose Bengal caused the selective inactivation.

Although the data are not shown, the electrophoretic mobility of the photomodified enzyme was identical with that of the native enzyme. Therefore, the molecular change within nitrate reductase induced by singlet oxygen is quite different from that caused by mild heat-treatment, ${ }^{12)}$ and might be an oxidation of certain residue(s).

The protective effect of NAD(P)H shown in Table II suggests that the modified residue(s) is involved in the electron inlet from NAD $(\mathrm{P}) \mathrm{H}$. It is generally accepted that cysteine residue(s) are involved in the electron transport between $\mathrm{NAD}(\mathrm{P}) \mathrm{H}$ and FAD in assimilatory nitrate reductase. ${ }^{14)}$ Vila et al. reported that the photomodification with flavins was reversed by the addition of $\mathrm{SH}$-reagents and suggested that the modified residue(s) might be cysteine. ${ }^{8)}$ However, we could not observe reactivation by $\mathrm{SH}$-reagents similar to the results of Vargas et al..$^{9)}$ Since the photooxidation of cysteine is thought to proceed as follows ${ }^{10)}$ : 
TABLE III. EFFECTS OF PCMB-PRETREATMENT ON THE Photomodification OF Nitrate Reductase

The enzyme $(45 \mu \mathrm{l}, 18 \mu \mathrm{g})$ with or without the addition of $10 \mu \mathrm{M}$ PCMB was incubated at $0^{\circ} \mathrm{C}$ for $10 \mathrm{~min}$, and then $5 \mu \mathrm{l}$ of $50 \mu \mathrm{M}$ Rose Bengal was added. After $15 \mathrm{~min}$ illumination $4 \mu \mathrm{l}$ aliquots of the samples were withdrawn and assayed for NADPH-nitrate reductase activity with or without the addition of $2 \mathrm{~mm}$ GSH to the assay mixture.

\begin{tabular}{|c|c|c|c|c|}
\hline \multirow{2}{*}{ GSH } & \multicolumn{2}{|c|}{ Native } & \multicolumn{2}{|c|}{$\begin{array}{l}\text { PCMB-treated } \\
\quad(\text { unit } / \mathrm{ml})\end{array}$} \\
\hline & Light & Dark & Light & Dark \\
\hline+ & 0 & 1.64 & 0 & 1.47 \\
\hline- & 0 & 1.69 & 0 & 0 \\
\hline
\end{tabular}

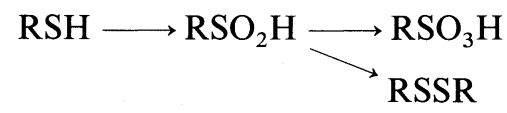

PCMB-blocked enzyme is expected not to be subject to photomodification so that the reactivation by GSH would be observed if the photomodified residue(s) would be cysteine. Thus, the results of Table III strongly suggest that residue(s) other than cysteine are also involved in the electron transport from NAD(P)H and photomodified by singlet oxygen.

Other than cysteine, several residues such as histidine, methionine, tryptophan, and tyrosine are expected to be subject to photooxidation. ${ }^{10)}$ The amino acid composition of our enzyme closely resembles those reported for barley, ${ }^{15)}$ Chlorella vulgaris, ${ }^{16)}$ and Ankistrodesmus braunii, ${ }^{17)}$ and exhibits no decrease of tyrosine after illumination (data are not shown). Because of the small amount of the enzyme preparation, we did not determine the exact contents of tryptophan and methionine. However, since the absorption spectra at UV region remained essentially unchanged after the photoillumination (data are not shown), tryptophan residues seemed not to be subject to the photooxidation by singlet oxygen in our experiment. Rose Bengal is an anionic dye, and is expected to form a shortlife complex with imidazole group(s) resulting in a relative selectivity toward histidine at neutral $\mathrm{pH}^{18)}$ From the results shown in Fig. 3 , histidine contents are closely related to the enzyme activity. There has been no report on the involvement of histidine residues in assimilatory nitrate reductase. Although further investigation is necessary to determine the number of modified histidine residues which participate in the NAD(P)H-linked activities, approximately four residues/enzyme molecule were calculated to be related directly to the loss of activity.

EFA is a reagent for chemical modification of proteins with a high degree of specificity, and has been used extensively to study the functions of histidine residues. ${ }^{19 \sim 22)}$ Quite similar to the results of photomodification, NADPH-linked activities were inactivated selectively by EFA. Histidine has been reported to exist near the pyridine nucleotide binding site of several enzymes ${ }^{23 \sim 25}$ and the FAD binding site of flavoenzymes. ${ }^{26,27)}$ Also our results suggest that histidine residues are involved in electron transport near the binding site of $\mathrm{NAD}(\mathrm{P}) \mathrm{H}$ in assimilatory nitrate reductase of $H$. anomala.

Acknowledgment. We are grateful to Dr. Kodama, Kodama Brewing Co., Ltd., for the gift of strain LKBY-1 of $H$. anomala and Dr. Odani, Department of Biochemistry, Niigata University School of Medicine, for carrying out the amino acid analysis.

\section{REFERENCES}

1) W. S. Silver, J. Bacteriol., 73, 241 (1957).

2) N. Minagawa and A. Yoshimoto, Agric. Biol. Chem., 47, 125 (1983).

3) E. J. Hewitt and B. A. Notton, "Molybdenum and Molybdenum-containing Enzymes," ed. by M. P. Coughlan, Pergamon Press, Oxford, 1980, pp. $273 \sim 325$.

4) P. J. Aparicio and J. M. Maldonado, "Nitrogen Assimilation of Plants," ed. by E. J. Hewitt and C. V. Cutting, Academic Press Inc., New York, N.Y., 1979, pp. $207 \sim 215$.

5) P. J. Aparicio, J. M. Roldán and F. Caleo, Biochem. Biophys. Res. Commun., 70, 1071 (1976).

6) J. M. Roldán, F. Caleo and P. J. Aparicio, Z. Pflanzenphysiol., 90, 467 (1978).

7) J. M. Roldán and W. L. Butler, Photochem. Photobiol., 32, 375 (1980).

8) R. Vila, A. Llobell, J. A. Barcena and A. Paneque, 
Biochem. Biophys. Res. Commun., 84, 943 (1978).

9) M. A. Vargas, S. G. Mauriño, J. M. Maldonado and P. J. Aparicio, Phochem. Photobiol., 36, 223 (1982).

10) C. F. Foote, "Free Radicals in Biology," Vol. II, ed. by W. A. Pryor, Academic Press Inc., New York, N.Y., 1976, pp. 85 133.

11) R. K. Main, M. J. Wilkins and L. J. Cole, J. Am. Chem. Soc., 81, 6490 (1959).

12) N. Minagawa and A. Yoshimoto, J. Biochem., 91, 761 (1982).

13) D. H. Spackman, W. H. Stein and S. Moore, Anal. Chem., 30, 1190 (1958).

14) N. K. Amy, R. H. Garrett and B. M. Anderson, Biochim. Biophys. Acta, 480, 83 (1977).

15) T. M. Kuo, D. A. Somers, A. Kleinhofs and R. L. Warner, Biochim. Biophys. Acta, 708, 75 (1982).

16) L. Giri and C. S. Ramadoss, J. Biol. Chem., 254, 11703 (1979).

17) M. A. De la Rosa and J. M. Vega, J. Biol. Chem., 256, 5814 (1981).

18) J. S. Bellin and C. A. Yankus, Arch. Biochem.
Biophys., 123, 18 (1968).

19) E. W. Miles, "Methods in Enzymology," Vol. XLVII, ed. by C. H. W. Hirs, Academic Press Inc., New York, N.Y., 1977, pp. $431 \sim 442$.

20) T. B. Rogers, R. A. Gold and R. E. Feeney, Biochem., 16, 2299 (1977).

21) G. G. Chang and R. Y. Hsu, Biochim. Biophys. Acta, 483, 228 (1977).

22) W. B. Melchior Jr. and D. Fahrney, Biochem., 9, 251 (1970).

23) M. Rippa, C. Picco and S. Pontremoli, J. Biol. Chem., 245, 4977 (1970).

24) S. H. Francis, B. P. Meriwether and J. H. Park, Biochem., 12, 346 (1973).

25) N. Tudball, R. Bailey-Wood and P. Thomas, Biochem. J., 129, 419 (1972).

26) W. H. Walker and T. P. Singer, J. Biol. Chem., 245 , 4224 (1970).

27) F. Müller, P. Hemmerich, A. Ehrenberg, G. Palmer and V. Massey, Eur. J. Biochem., 14, 185 (1970). 